\title{
Innovation in Education through Student Final Project
}

\author{
Muslimah Susilayati ${ }^{1}$ \\ IAIN Surakarta,Indonesia \\ Correspondence: muslimahsm@gmail.com
}

\begin{abstract}
To optimize the role and education function, university needs realistic experiment, continuously develops itself to meet the challenge and society and industrial demand. That efforts can be done by preparing students for making innovation in education through research \& development of the final project. This study is aim to provide an overview about the steps taken to provide student to create innovation in education. This is a library reasearch. The data was taken from written materials through literary studies. The result of study are showed that innovation in education can be done through student final project by using R\&D experiment, action reasearh, and qualitatif reasearch. There are four steps in R\&D experiment, those are 1) developing model; 2) validating model; 3) trial; and 4) analyzing the result of the trial and polishing model. Furthermore, in action research and qualitative reseach, objective of model formulation and development process are required. The product of innovation in education can be in form of a model, a method, a procedure, a book, a module, an evaluating instrument, and a learning program, that have been passed quality test so eligible to be used in education.
\end{abstract}

Keywords. innovation; education; reasearch and development; final project 


\section{INTRODUCTION}

The role and function of Higher Education has stated in the Law of the Republic of Indonesia Number 12 of 2012. One indicator can be seen from scientific papers. The current number of scientific papers still very low. To optimize that role and education function, university needs realistic experiment, continuously develops itself to meet the challenge and society, even for industrial demands. That effort can be done by preparing students for making innovation in education through research and development of their final project. This study aim is to provide an overview about the steps taken to provide students to create innovation in education. Depends on Global Innovation Index 2015, QS university ranking, average score top $3 *$ indicates a strength in Research and Development (R\&D).

\section{METHOD}

This is a library research. The data was taken from written materials through literary studies. The main source of data research taken from books, journals, and reports related. The analytical method is descriptive and critical analysis using inductive thinking technique. Descriptive analysis is a method related with collecting, summarizing, and data presenting, so it is ready to be analyzed. Critical thinking is needed too. Gunawan (2003) states that critical thinking skills are the ability to think at the complex level and use the process of analysis and evaluation. Critical thinking involves inductive thinking skills such as recognizing the relationship, that analyze the issue is open, determine cause and effect, making inferences and to calculate the relevant data. Rahmat (2010) argues critical thinking is synonymous with decision making, strategic planning, scientific process, and problem solving. Juha (2010) states "Critical thinking is reasonable, reflective thinking, focused on deciding what to believe or do". Paul, R., \& Elder, L. (2012) states "Critical thinking is the art of thinking about thinking while thinking to the make thinking better". Therefore, that method becomes important for this research.

\section{FINDING}

Depends on Organisation for Economic Cooperation and Development (OECD) discussion paper (2009), there are important arguments to push for innovation in education as a means to maximise the value of the public investment (Lekhi, 2007). First of all, innovations can improve the learning outcomes and the quality of the provision of education, for example by helping the shift out of a $20^{\text {th }}$ century "mass production"mode to amore personalised mode (Albury, 2005, Mulgan and Albury, 2003). Society is diverse, and education needs are also diverse. Changes in the educational system, e.g. the introduction and use of ICT, can help customise th educational process. Second, public organisations are often 
under as much pressure as businesses to improve efficiency, minimising costs and maximise the "bang for the buck". Mulgan and Albury (2003) argue that there has been a tendency for costs in all public services to rise faster than those in the rest of the economy, and education is not an exception. Innovation is then regarded to be the stimulus for a more efficient provision of these services. Third, education should be relevant to society and the national economy. As these are categorised as "hyper-changing" (Barret, 1998: 288), the education sector should introduce the necessary changes that permit to adapt to these needs. Finally, education is also perceived in more countries as a means to enhannce equity. İnnovation could also help enhance the equity in the access and use of education.

\section{Defining "Innovation in education".}

The term "innovation" is more often used than defined although there are dozens of definitions used in different context and disciplines. For statistical purposes, perhaps the most widely accepted definition of innovation comes from the Oslo Manual (OECD/Eurostat 2005) that defines innovation as "the implementation of a new or significantly improved product (good or service) or process, a new marketing method, or new organizational method in business practices, workplace organization or external relations". This definition shares a consistent theme with other available definitions: innovation is typically understood as the successful introduction of something new and useful. In this definition, it is important to highlight that "new" should be interpreted as context-specific, organization specific, rather than universal or market-wide.

This definition has been widely applied to the private sector and it can be also the applicable to education. Educational organizations, e.g. schools, universities, training centre, introduce (1) new products and service, e.g. new curricula, (2) new processes for delivering its services, use of ICT in e-learning services, (3) new ways of organizing their activities, e.g. ICT to communicate with students, parents, (4) new marketing techniques, e.g. pricing of postgraduate courses. These new practices are intended to improve the education service in one way or another, and therefore, innovation in education should be regarded as "improvements".

However, the notion of "improvement" in many public services, including education, can be elusive and the use of this definition challenged. The perception of "improvement" depends on the perspective of the stakeholders, who may wear several hats: consumer, citizen and tax-payer (Parston, 2007). Companies in the private sector operate with a single objective and a single bottom line. On the contrary, public organizations count on a multiplicity of objectives, e.g. increase quality, equity, coverage and efficiency, less commensurable, that 
can even conflict. As a result, improvements in education can be perceived differently based on the respondent, and this has consequences on the perspective that has to be chosen and on the validity and limitation of the information that may be gathered. Moreover, cultural values, social policies and political goals are deeply embedded in different societies and influence the prioritization of the different objectives of education. This can change over time as the result of shifts in circumstances and citizen expectation.

\section{Barriers to innovation in education.}

Innovations is not merely about a final product, but also about the conditions that must be in place to allow innovators to see a problem in new light, create potential solutions, refine their approach, and ultimately bring to scale effective ideas, products, processes, and platforms. Innovation in education, this kind of work needs to happen at the student, school and system levels. We have some fundamental barriers to innovation in education. That are weak knowledge base, research divorced from problems of practice, and ineffective uptake and dissemination.

Compared to other professional fields like medicine, which has professional knowledge standards, a constantly improving knowledge base, and advanced mastery indicators like the Board Certification process for medical doctors, the knowledge base regarding what works in advancing student achievement and organizing education practice to encourage innovation is very weak. As a result, there is no commonly accepted body of knowledge that is universally mastered as a prerequisite for entering the profession, nor a standard for advanced mastery.

Currently, educational research sits inside government-funded laboratories and universities that are largely isolated within schools of education, and is often aligned to tenure incentives rather than problem-based needs in the field. There is little sense of urgency to disseminate knowledge and bring innovative ideas or knowledge into the development cycle and to scale. Knowledge development often doesn't meet basic pragmatic requirements in the field. Problems of practice are cross-disciplinary, but the current educational research rarely.

There is not enough attention paid to diffusing knowledge and innovation, so that benefits reach people and organizations beyond those it was originally developed to serve. This is in part due to the isolation of practitioners and their lack of rewards or incentives for adopting innovative practices. But it is also because too often, dissemination means the development of lengthy reports that sit on dusty shelves or on unseen Web sites that fail to inform real practice.

\section{The opportunity to innovate.}


Innovation in education can be done effectively and efficiently trough student final project. Depends on higher educational levels, there are three types: thesis for S1 (skripsi), thesis for S2, and dissertation for S3. Students can take final exam and graduation after finished their student final project. In line with Dirjen Dikti's Letter No. 152/E/T/2012, starting from graduation after August 2016 enacted new rule: students must produce papers published in scientific journals to undergraduate for Bachelor program, students should have resulted a paper published in national scientific journal preferably Dikti accredited to graduate for Master program, and students should have resulted in a paper accepted for international journals publication to graduate the Doctoral program.

There are many differentiates between thesis for Bachelor's program, thesis for Master's program, and dissertation for Doctoral program. Sometimes the differentiations influence $\mathrm{S} 1 / \mathrm{S} 2$ student mindset that research and development is not suitable for their final projects. Even though, student final project with research and development models offer more innovation chance. Usually, it is used in doctoral final project that must be required to discover new things. Research and development models are rarely used by Bachelor/Master students. They think that Research and development is difficult while it must not be complicated. Students can make a simple final project with research and development models, producing product innovation. So, research and development models can be used by all students, following some steps. The crucial differences are only in range of issues and publications, but the processes are same.

\section{Research and development steps}

$\mathrm{R} \& \mathrm{D}$ is efforts to make really new innovation or improve by modifying and upgrading who was been there before. There are so many models of research and development. R\&D experiment research, in action research, and qualitative research are recommended to innovate in education trough student final project. Experiments are controlled by variables, so they are the best of quantitative design to use to establish probable cause and effect (Creswell, 2008). Bock (2001) defines: an experiment acquires data to measure the performance of the solution under controlled condition in a laboratory. That why $\mathrm{R} \& \mathrm{D}$ is correlated with experiment to analyze the product results. Even, R\&D is named Scientific Research \& Experimental Development (SR\&ED).

A simple research and development experiment step, modifying Dick and Carey model (Borg and Gall, 2003) at least consist of four steps: developing, validating, trials, and analyzing the result of the trials to be polished. The steps are closely correlated with student final project steps. There five chapters must be arranged for student final project report. 
Chapter one past three discuss about background, aims, theory, and method of experiment, correlating with developing and validating steps. Chapter four past five discuss about results and conclusions are consist of trials and analyzing material result steps.

For combination quantitative and qualitative methodology, innovation in education can also be done by research and development trough student final project. That mixed method is expected to obtain completely result models. Action research includes in applied research that combine knowledge, research, and action. It is "learning by doing" that applied in their reality work. Workers can always produce new ideas that implemented to improve their work result become more effective and efficient. As well in education, students can always produce innovation trough $\mathrm{R} \& \mathrm{D}$ in action or qualitative research at least when they take the final project as reality efforts to make improvements in education. Furthermore, in action research and qualitative research, objective of model formulation and model development process are required. The table 1 bellow showed types, steps and contents of innovation in education through student final project.

Table 1. Types, steps and contents of innovation in education through student final project

\begin{tabular}{|c|c|c|c|}
\hline \multirow{2}{*}{$\begin{array}{l}\text { Students } \\
\text { Final Project } \\
\text { Thesis/Dissertation }\end{array}$} & \multicolumn{3}{|c|}{ Research and Development (R\&D) types, steps and content } \\
\hline & $\begin{array}{l}\text { Experiment: } \\
\text { probandus testing }\end{array}$ & $\begin{array}{l}\text { In action: } \\
\text { testing by doing } \\
\text { (cycles-participatory) }\end{array}$ & $\begin{array}{l}\text { Qualitative: } \\
\text { reviewer testing }\end{array}$ \\
\hline Chapter I & $\begin{array}{l}\text { Pre-developing: } \\
\text { determine aims }\end{array}$ & $\begin{array}{l}\text { Pre-developing: } \\
\text { determine objectives }\end{array}$ & $\begin{array}{l}\text { Pre-developing: } \\
\text { determine objectives }\end{array}$ \\
\hline Chapter II & $\begin{array}{l}\text { Pre-developing: find } \\
\text { correlated theory }\end{array}$ & $\begin{array}{l}\text { Pre-developing: find } \\
\text { correlated theory }\end{array}$ & $\begin{array}{l}\text { Pre-developing: find } \\
\text { correlated theory }\end{array}$ \\
\hline Chapter III & $\begin{array}{l}\text { Pre-developing: } \\
\text { setting methodology }\end{array}$ & $\begin{array}{l}\text { Pre-developing: } \\
\text { setting methodology }\end{array}$ & $\begin{array}{l}\text { Pre-developing: } \\
\text { setting methodology }\end{array}$ \\
\hline Chap & $\begin{array}{lr}\text { - } & \text { Developing: make } \\
\text { draft product and } \\
\text { instrument } \\
\text { research. } \\
\text { - } \\
\text { Validating: } \\
\text { draft } & \text { product } \\
\text { quality } & \text { with } \\
\text { lectures } & \text { as } \\
\text { validator then } \\
\text { revising that } \\
\text { become products. } \\
\text { Trials: product } \\
\text { testing by } \\
\text { probandus, then } \\
\text { filling data in }\end{array}$ & 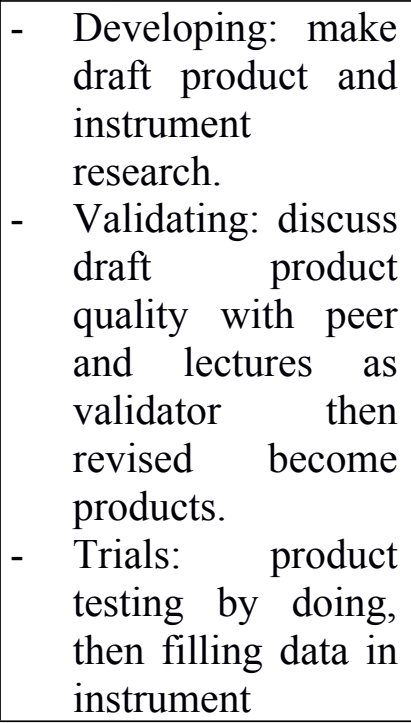 & $\begin{array}{lr}\text { - } & \text { Developing: make } \\
\text { draft product and } \\
\text { instrument } \\
\text { research. } \\
\text { - } \\
\text { Validating: discuss } \\
\text { draft product } \\
\text { quality } & \text { with } \\
\text { lectures } & \text { as } \\
\text { validator then } \\
\text { revising that } \\
\text { become products. } \\
\text { Trials: product } \\
\text { testing then } \\
\text { reviewers, then } \\
\text { filling data in }\end{array}$ \\
\hline
\end{tabular}




\begin{tabular}{|c|c|c|c|}
\hline & $\begin{array}{l}\text { instrument } \\
\text { research. } \\
\text { - Analyzing: make a } \\
\text { statistical } \\
\text { presenting to } \\
\text { analyze based on } \\
\text { eligibility criteria. } \\
\text { The product is the } \\
\text { final product if it is } \\
\text { eligible, but must } \\
\text { be revised if not. } \\
\text { Researchers can } \\
\text { describe 5W1H } \\
\text { about the eligible } \\
\text { final product. }\end{array}$ & $\begin{array}{l}\text { research compared } \\
\text { with the previous } \\
\text { cycle data. } \\
\text { - Analyzing: make a } \\
\text { statistical } \\
\text { presenting to } \\
\text { analyze based on } \\
\text { eligibility criteria. } \\
\text { The product is the } \\
\text { final product if it is } \\
\text { eligible, but must } \\
\text { be revised if not. } \\
\text { Researchers can } \\
\text { describe 5W1H } \\
\text { about the eligible } \\
\text { final product, } \\
\text { correlated with } \\
\text { cycle research too. }\end{array}$ & $\begin{array}{l}\text { instrument } \\
\text { research. } \\
\text { - Analyzing: make a } \\
\text { statistical } \\
\text { presenting to } \\
\text { analyze based on } \\
\text { eligibility criteria. } \\
\text { The product is the } \\
\text { final product if it is } \\
\text { eligible, but must } \\
\text { be revised if not. } \\
\text { Researchers can } \\
\text { describe 5W1H } \\
\text { about the eligible } \\
\text { final product. }\end{array}$ \\
\hline Chapter V & $\begin{array}{l}\text { Describes } \\
\text { achievement of aims } \\
\text { on pre-developing } \\
\text { steps. }\end{array}$ & $\begin{array}{l}\text { Describes } \\
\text { achievement of } \\
\text { objectives on } \\
\text { pre-developing steps. }\end{array}$ & $\begin{array}{l}\text { Describes } \\
\text { achievement of aims } \\
\text { on pre-developing } \\
\text { steps. }\end{array}$ \\
\hline
\end{tabular}

\section{Improvements result in education}

The product of innovation in education can be in form of a model, a method, a procedure, a book, a module, an evaluation instrument, and a learning program, that have been passed quality test so eligible to be used in education. The Indonesian education systems is managed by two ministries: The Ministry of Education and Culture (MoEC), which is responsible for over $80 \%$ of all students, teacher and schools, and the Ministry of Religion (MoRA), which is responsible for the reminder including Islamic schools or madrasah. Depends on data MoRA in 2013/2014, there are 678 religious Colleges with 613.665 students. If almost all of them make an innovation in education effort at least on the final project, it means that Indonesia will have 613.665 innovations in religious education and much more in MoEC.

\section{CONCLUSION}

The result study is showed that innovation in education can be done through student final project by using R\&D experiments, action research and qualitative research. There are for steps in R\&D experiments, those are 1) developing model, 2) validating model, 3) trials, and 4) analyzing the result of the trials, and polishing model. Furthermore, in action research and qualitative research, objective of model formulation and model development process are required. The product of innovation in education can be in form of a model, a method, a 
procedure, a book, a module, an evaluation instrument, and a learning program, that have been passed quality test so eligible to be used in education. These innovations could impact on improvement of society and industrial demand. 


\section{REFERENCES}

Albury, D. (2005). Fostering innovation in public services. Public Money and Management.

Barret, D. (1998). Paradox Process: Creative business solutions where you least expect to find them. AMACOM: New York.

Bock, Peter. (2001). Getting it right: $R \& D$ method in science and engineering. San Diego: Academia Press.

Cornell University, INSEAD, and WIPO. (2015): The global innovation index 2015: Effective innovation policies for development. Fontainebleau, Ithaca, and Geneva.

Gunawan, Adi W. (2003). Genius learning strategy petunjuk praktis untuk menerapkan accelarated learning. Jakarta: Gramedia Pustaka Utama.

Juha, Mervat Amin. (2010). Thinking skills critical thinking- 2 chapter. Zaid .IQ

Lekhi, R. (2007). Public service innovation, A research report to the Work Foundation's Knowledge Economy Programme. London.

Mulga, G and Albury. (2003). Innovation in public sector, strategy unit, cabinet office. London.

Number of Universities, Students, and Lecturers Under Ministry of Religious Affairs by Province, 2013/2014. Retrieved form: https://www.bps.go.id/linkTabelStatis/view/id/1840.

Putra, Nusa. (2015). Research \& development, penelitian dan pengembangan: Suatu pengantar. Jakarta: Raja Gravindo Persada.

Potter, Mary Lane. (2010). From search to research: Developing critical thinking through web research skills C 2010 Microsoft Corporation.

Rahmat. (2011). Berpikir kritis. Retrieved from: http:/gurupembaharu.com/berpikir-kritis/

OECD Discussion Paper. Measuring innovation in education and training, Paris, 11 June 2009. Retrieved from: http://www.oecd.org/edu/ceri/43787562.pdf.

Smith, Kim. (2009). Innovation in public education: Problems and opportunities. New York: NewSchools Venture Fund. 